\title{
Quality of life, religiosity, and anxiety and depressive symptoms in liver transplantation candidates*
}

\author{
Qualidade de vida, religiosidade e sintomas ansiosos e \\ depressivos em candidatos a transplante hepático \\ Calidad de vida, religiosidad y síntomas ansiosos y depresivos \\ en candidatos a trasplante hepático
}

How to cite this article:

Paglione HB, Oliveira PC, Mucci S, Roza BA, Schirmer J. Quality of life, religiosity, and anxiety and depressive symptoms in liver transplantation candidates. Rev Esc Enferm USP. 2019;53:e03459. DOI: http://dx.doi.org/10.1590/S1980-220X2018010203459

\section{Heloisa Barboza Paglione ${ }^{1}$ \\ Priscilla Caroliny de Oliveira ${ }^{1}$ \\ Samantha Mucci² $^{2}$ \\ Bartira de Aguiar Roza ${ }^{1}$ \\ Janine Schirmer ${ }^{1}$}

* Extracted from the dissertation: "Qualidade de vida, religiosidade e sintomas ansiosos e depressivos em candidatos a transplante hepático", Universidade Federal de São Paulo, 2018.

1 Universidade Federal de São Paulo, Escola Paulista de Enfermagem, São Paulo, SP, Brazil.

${ }^{2}$ Universidade Federal de São Paulo, Escola Paulista de Medicina, São Paulo, SP, Brazil.

\begin{abstract}
Objective: To evaluate quality of life, religiosity and anxiety and depressive symptoms in liver transplant candidates. Method: An epidemiological and cross-sectional study carried out with liver transplant candidates attended at the outpatient clinic of a University Hospital from 2014 to 2016. Results: Fifty (50) patients with a mean age of 52.5 years old participated in the study, predominantly male $(58.0 \%)$, having access to primary education (48.0\%), Model for End-Stage Liver Disease between 10-19 and having viral hepatitis as the main etiology. They presented an average quality of life score (4.1), high intrinsic religiosity index (5.6) and the presence of anxiety (52.0\%) and depressive symptoms (48.0\%). It was possible to observe an association between religiosity and quality of life in the worry domain, with higher non-organizational religiosity leading to higher quality of life; anxiety and depressive symptoms were not associated with quality of life and religiosity. However, patients with higher levels of education were more likely to present depressive symptoms. Conclusion: The analysis of quality of life and religiosity was significant, reinforcing the need for the care team to consider religiosity as a coping strategy for the disease.
\end{abstract}

\section{DESCRIPTORS}

Liver Transplantation; Anxiety; Depression; Quality of Life; Spirituality; Nursing Care. 


\section{INTRODUCTION}

Liver transplantation (LT) is indicated for patients with progressive, irreversible liver disease and no other treatment alternatives ${ }^{(1)}$.

In the last quarter of 2017 , there were 1,235 people enrolled on the liver transplant list in Brazil. The mortality rate of patients on the list is around 20.0\%, which means that one fifth of patients will die before receiving a transplant due to the severity of the disease. Liver disease can have several causes such as alcoholic cirrhosis, hepatocarcinomas, or viral hepatitis, among others ${ }^{(2)}$.

Liver disease is considered a chronic disease, and therefore it accompanies the individual for a long period of their life, being able to present moments of worsening (agitation) or moments of sensitive improvement ${ }^{(3)}$.

Patients who have liver disease have several limitations imposed on them by the disease. The presence of innumerable symptoms, which are often non-specific at the disease onset (i.e. anorexia and malaise) can progress to more severe and disabling symptoms such as ascites and encephalopathy with the progression of liver disease, which can cause important impairments in quality of life (QOL) and mental health of liver transplant candidates due to never before experienced situations ${ }^{(4)}$.

The various changes and limitations, in addition to the various necessary adaptations (food, medication, financial, physical, among others), have an impact on the quality of life of patients who have liver disease. Measuring the quality of life of these patients is an important measure of health impact ${ }^{(5-6)}$.

Faced with health problems and the need to re-signify illness, patients' religiosity appears as an important adaptive resource. Studies show that religiosity can positively contribute to the clinical evolution of patients, improve health behaviors, reduce anxiety and depressive symptoms, among other benefits ${ }^{(7-8)}$.

Candidates for liver transplantation experience unusual situations, so it is important to know the aspects associated with their experience of illness in order to perform improvements in the care of these patients. Liver transplantation is a complex situation that requires a multiprofessional approach in the pre-, intra- and post-transplantation, and nursing that permeates all stages of this process can be key to implementing new practices and further individualizing the patient care.

Therefore, the objective of this study was to evaluate the quality of life, religiosity and symptoms of anxiety and depression in liver transplantation candidates.

\section{METHOD}

\section{StUdY TYPE}

This was a cross-sectional epidemiological study with liver transplantation candidates attended at the University Hospital of the Universidade Federal de São Paulo (UNIFESP) from August 2014 to May 2016.

\section{Study POPULATION}

All candidates for liver transplantation on the single technical registry waiting list of the UNIFESP liver transplant outpatient clinic with active (who compete for the organ offered) and semi-active status (temporarily do not compete for the organ offered) of both genders, who were 18 years of age or older, and who were attended at the outpatient clinic from 2014 to 2016 were invited to participate in the study. Patients with severe encephalopathy and those hospitalized in the pre-transplant evaluation period were excluded from the study.

\section{SAMPLE}

The sample was by convenience, since the activities of the resident group occurred between 2014 and 2016 and were constituted by the patients that met the previously-defined inclusion and exclusion criteria. Nine of the 67 evaluated patients were excluded for refusing to participate in the study (but received multiprofessional care throughout the pretransplant period), and eight more due to incomplete data. Thus, the total sample consisted of 50 patients.

\section{Data collection}

The selected patients were initially contacted by telephone for a subsequent pre-transplant multiprofessional consultation appointment. All patients were evaluated by a pair of specialists from different professions who were previously trained to perform the initial multiprofessional evaluation. The patients who accepted to participate in the study read and signed the free and Informed Consent Form and answered the socio-demographic questionnaire form before application of the evaluation instrument.

The candidates were submitted to an evaluation of clinical, psychological, pharmaceutical, physiotherapeutic and nursing aspects by pre-established instruments by the resident professional team of the UNIFESP Transplant and Organ Procurement Program of the Multiprofessional Residency.

The following instruments were used: Sociodemographic Data Record: an instrument elaborated according to the evaluation criteria of the Brazilian Institute of Geography and Statistics (IBGE - Instituto Brasileiro de Geografia e Estatistica), with the purpose of discovering the profile of the study population; Multiprofessional Initial Evaluation: semi-structured interview script that addresses the clinical and psychological aspects of the disease, the daily living habits and understanding of the disease ${ }^{(9)}$; DUKE (DUREL) Religiosity Scale: a scale validated for the Brazilian population consisting of five items which measure three of the main dimensions of religious involvement related to health outcomes. The first two items (organizational religiosity $\mathrm{OR}$, non-organizational religiosity - NOR) are related to physical, mental and social health indicators (ranging from 1 - more than once a week to 6 - never), and the other three items (intrinsic religiosity - IR) are related to social support and health outcomes (ranging from 1 - totally true for me to 5 - this is not true). The items regarding the analysis should be analyzed separately by size ${ }^{(10)}$, being: OR - attendance to religious meetings; NOR - private religious activities such as prayer, reading religious texts, etc.; and IR - internalization and full experience of religiosity as the main objective of the 
individual. Next, the Chronic Liver Disease Questionnaire (CLDQ): a questionnaire validated for the Brazilian population consisting of 29 items which assess quality of life, and are distributed in the following domains: fatigue, activity, emotional function, abdominal symptoms, systemic symptoms and worry, presenting levels of response which range from one (all the time) to seven (never). The score of each domain is comprised of the sum of the answers divided by the number of questions included in that domain. The total score is obtained by adding the domains and divided by the total number of domains. Thus, considering a scale of 1 to 7 , the quality of life was stratified into poor, medium and $\operatorname{good}^{(11)}$. Lastly, the Patient Health Questionnaire-4 (PHQ4): A four-item scale, in which two are related to anxiety symptoms, and two to depressive symptoms. It is a brief scale and has quick and easy identification of these two mental disorders. The questions presented on the scale refer to the last two weeks of the patient's life, and range from zero (never happens) to three (almost every day), with the total score (psychological distress) of the scale equal to $12^{(12)}$.

\section{DATA ANALYSIS AND PROCESSING}

A spreadsheet (Microsoft Excel ${ }^{\otimes}$ software) was developed to compile the data using information from the pretransplant evaluation instruments for the descriptive analysis. Spreadsheets were also used as the basis for the statistical analysis in a specific program (Statistical Package for the Social Sciences - SPSS ${ }^{\oplus}$ - version 20.0.).

The data were analyzed descriptively, presenting categorical variables in absolute and relative frequencies, and numerical in summary measures. We used the Spearman and Pearson correlations to evaluate the linear associations between the numerical variables. Student's t-test and analysis of variance (ANOVA) were used to compare means between two and more than two groups. The non-parametric Mann-Whitney and Kruskal-Wallis tests were used in case of violating the normality assumption on the Student's t-Test and ANOVA or the presence of groups with a small number of cases, while the groups with distinct means were identified using the Dunn-Bonferroni multiple comparisons to maintain the overall level of significance. Multiple linear regressions were used in order to simultaneously evaluate the effects of demographic, clinical and religious characteristics on quality of life, and logistic regressions were used for anxiety, depression and psychological distress. Due to the sample size, the variables whose associations with the dependent variables were significant to $10.0 \%$ of the univariate analysis were selected for the initial models, in addition to the religiosity scores. Nonsignificant variables at $5.0 \%$ were subsequently excluded one by one in order of significance, except for religiosity. The linear regression model assumes normality in the data, which was verified using the Kolmogorov-Smirnov test. A significance level of $5.0 \%$ was used for all statistical tests ${ }^{(13-14)}$.

\section{ETHICAL ASPECTS}

In accordance with the provisions of Resolution no. 466/2012 of the National Health Council, the project was submitted and approved by the Ethics and Research Committee of UNIFESP and Plataforma Brasil under the opinion 623,082, in 2014.

\section{RESULTS}

Data from 50 patients who had a mean age of 52.5 years (Standard Deviation $-\mathrm{SD}=12.1$ years) were analyzed, with a minimum age of 24 years and a maximum of 71 years.

In analyzing the profile of candidates for liver transplantation, a predominance of males (58.0\%) and of the Catholic religion was observed in $56.0 \%$ of the candidates, followed by $30.0 \%$ of the evangelical religion. With regard to family income and schooling, $48.0 \%$ had monthly incomes of up to two minimum wages (MW) - the monthly minimum wage for 2014 was $R \$ 724.00$, reaching $R \$ 880.00$ in 2016 - and only had access to elementary education.

Regarding the clinical characteristics of the patients, at least $30.0 \%$ of the candidates for LT had Systemic Arterial Hypertension (SAH) and Diabetes Mellitus (DM). It is also noted that $70.8 \%$ had MELD (scoring system, which can range from 6 to 40 points, used to assess the severity of liver disease and to predict patient survival in the next 3 months - the higher the score, the higher the severity and worse the patient's survival) score of between 10 and 19 points. Regarding the liver disease etiology, 31.3\% had viral hepatitis, and $22.9 \%$ of patients had non-alcoholic hepatic steatosis and alcoholic cirrhosis.

Table 1 presents the anxiety and depression scores, quality of life and religiosity of LT candidates.

Table 1 - PHQ-4, CLDQ and DUKE scores of liver transplant candidates - São Paulo, SP, Brazil, 2014-2016.

\begin{tabular}{lc}
\hline & $\mathrm{N}(\%)$ \\
\hline PHQ4 & $26(52.0)$ \\
Anxiety & $23(46.0)$ \\
Depression & \\
Total - classification & $13(26.0)$ \\
Normal (up to 2) & $15(30.0)$ \\
Light (3-5) & $12(24.0)$ \\
Moderate (6-8) & $10(20.0)$ \\
Severe (9-12) & Média \pm DP \\
\hline CLDQ & $4.4 \pm 1.8$ \\
Abdominal & $3.6 \pm 1.8$ \\
Fatigue & $4.4 \pm 1.4$ \\
Systemic Symptom & $4.1 \pm 1.8$ \\
Activity & $4.4 \pm 1.4$ \\
Emotional function & $3.8 \pm 2.0$ \\
Worry & $4.1 \pm 1.4$ \\
Total & \\
\hline DUKE & $3.6 \pm 1.8$ \\
Organizational & $3.2 \pm 1.8$ \\
Non-organizational & $5.3 \pm 2.9$ \\
\hline Intrinsic & \\
\hline & \\
\hline
\end{tabular}


According to Table $1,52.0 \%$ and $46.0 \%$ presented anxiety and depression symptoms, respectively. Only $26.0 \%$ did not present anxiety or depressive symptoms at the time of the evaluation.

With regard to quality of life, it can be observed that the patients presented worse scores on the items fatigue and worry and better scores for the other items, with a mean of 4.1 in the total score.

The religiosity index of the candidates is divided into three items: organizational religiosity $(\mathrm{OR})$ - mean 3.6; nonorganizational religiosity (NOR) - mean 3.2; and intrinsic religiosity (IR) - mean 5.3.

Cross-checks were performed with the six domains that assess quality of life through the CLDQ instrument and the characteristics of the LT candidates, and only the worry domain presented statistical significance, according to Table 2 .

According to Table 2, there were differences in means of CLDQ - the worry domain with the income of the patients $(\mathrm{p}=0.041)$. Thus, patients with monthly incomes of up to one minimum wage presented a higher average in this domain (3 more points) compared to those who received three minimum wages or more.

There was a positive correlation between CLDQ emotional function and DUKE score - non-organizational religiosity $\left(r^{\mathrm{s}}=0.292, \mathrm{p}=0.039\right)$, pointing out that the higher this aspect of religiosity, the greater the emotional function domain (less worry).

According to Table 4, the religiosity scores on the DUKE were not shown to be associated with PHQ-4 (anxiety and depression symptoms). However, education (high school and more) was significant for depression symptoms ( $p=0.041)$. Thus, these patients are four times more likely to present depression symptoms than those with less schooling.
Table 2 - CLDQ Summary Measures - Worry for Characteristics of Liver Transplant Candidates - São Paulo, SP, Brazil, 2014-2016.

\begin{tabular}{|c|c|c|c|c|}
\hline & Mean & $\begin{array}{l}\text { Standard } \\
\text { deviation }\end{array}$ & $\mathbf{N}$ & $\mathbf{P}$ \\
\hline Gender & & & & 0.893 \\
\hline Male & 3.9 & 2.0 & 29 & \\
\hline Female & 3.8 & 2.1 & 21 & \\
\hline Education & & & & $0.423^{\mathrm{a}}$ \\
\hline Literate/Incomplete Elementary & 4.1 & 2.3 & 18 & \\
\hline Completed Elementary school & 4.1 & 1.9 & 15 & \\
\hline Completed highschool and more & 3.3 & 1.9 & 17 & \\
\hline Religion & & & & $0.680^{b}$ \\
\hline Catholic & 4.1 & 2.2 & 28 & \\
\hline Evangelical & 3.3 & 1.9 & 15 & \\
\hline Other & 4.1 & 1.3 & 4 & \\
\hline No religion & 3.7 & 2.0 & 3 & \\
\hline Income & & & & $0.041^{\mathrm{b}}$ \\
\hline Up to $1 \mathrm{MW}$ & $6.4^{\mathrm{A}}$ & 1.1 & 4 & \\
\hline 1 to $2 \mathrm{MW}$ & 4.0 & 2.2 & 20 & \\
\hline 2 to $3 \mathrm{MW}$ & 3.4 & 1.7 & 12 & \\
\hline More than $3 \mathrm{MW}$ & $3.1^{\mathrm{B}}$ & 1.9 & 14 & \\
\hline MELD Classification & & & & $0.519^{b}$ \\
\hline$\leq 9$ & 2.5 & 1.4 & 3 & \\
\hline $10-19$ & 3.9 & 2.0 & 34 & \\
\hline $20-29$ & 3.9 & 2.6 & 11 & \\
\hline Underlying disorder & & & & $0.645^{\mathrm{a}}$ \\
\hline Viral hepatitis & 3.2 & 1.8 & 15 & \\
\hline Hepatocarcinoma & 3.9 & 2.0 & 10 & \\
\hline Fatty Liver/Alcoholic Cirrhosis & 4.1 & 1.6 & 11 & \\
\hline Others & 4.1 & 2.7 & 12 & \\
\hline
\end{tabular}

p: descriptive level of the Student's t-test, ANOVA (a) or Kruskal-Wallis ( ${ }^{(b)}$. (A) and (B) presented different means according to Dunn-Bonferroni multiple comparisons.

Table 3 - Correlations between CLDQ (six domains and total) and the variables age and religiosity scores (DUKE) - São Paulo, SP, Brazil, 2014-2016.

\begin{tabular}{|c|c|c|c|c|c|c|c|c|}
\hline & \multirow{2}{*}{\multicolumn{2}{|c|}{$\begin{array}{c}\text { Pearson Correlation }\left(\mathrm{r}^{\mathrm{P}}\right) \\
\text { Age (years) }\end{array}$}} & \multicolumn{6}{|c|}{ Spearman Correlation $\left(\mathrm{r}^{\mathrm{S}}\right)$} \\
\hline & & & \multicolumn{2}{|c|}{ DUKE - Organizational } & \multicolumn{2}{|c|}{ DUKE - Non-organizational } & \multicolumn{2}{|c|}{ DUKE - Intrinsec } \\
\hline & Estimated & $\mathbf{P}$ & Estimated & $\mathbf{P}$ & Estimated & $\mathbf{P}$ & Estimated & $\mathbf{P}$ \\
\hline Abdominal & 0.001 & 0.995 & -0.222 & 0.122 & -0.253 & 0.076 & -0.134 & 0.355 \\
\hline Fatigue & -0.213 & 0.137 & 0.014 & 0.925 & 0.131 & 0.364 & 0.070 & 0.628 \\
\hline Systemic symptom & -0.154 & 0.287 & -0.145 & 0.314 & -0.071 & 0.626 & -0.040 & 0.780 \\
\hline Activity & -0.167 & 0.246 & -0.238 & 0.097 & -0.149 & 0.301 & -0.095 & 0.511 \\
\hline Emotional Function & 0.200 & 0.163 & 0.175 & 0.225 & $0.292 *$ & 0.039 & 0.129 & 0.374 \\
\hline Worry & 0.072 & 0.621 & 0.171 & 0.235 & 0.242 & 0.090 & 0.214 & 0.135 \\
\hline CLDQ - total & -0.056 & 0.699 & -0.083 & 0.565 & 0.017 & 0.907 & 0.038 & 0.796 \\
\hline
\end{tabular}

$\mathrm{N}=50 ;{ }^{*} \mathrm{p}<0.05$.

Table 4 - Logistic regression results for PHQ4 dimensions and total - final models - São Paulo, SP, Brazil, 2014-2016.

\begin{tabular}{|c|c|c|c|c|c|c|}
\hline & \multicolumn{6}{|c|}{ PHQ -4 } \\
\hline & \multicolumn{2}{|l|}{ Anxiety } & \multicolumn{2}{|l|}{ Depression } & \multicolumn{2}{|c|}{ Psychological suffering } \\
\hline & OR (CI95.0\%) & $\mathbf{P}$ & OR $(\mathrm{Cl} 95.0 \%)$ & $\mathbf{P}$ & OR (CI95.0\%) & $\mathbf{P}$ \\
\hline \multicolumn{7}{|l|}{ Duke } \\
\hline OR & $0.83(0.56-1.23)$ & 0.351 & $1.19(0.79-1.81)$ & 0.407 & $1.02(0.66-1.59)$ & 0.913 \\
\hline NOR & $0.97(0.66-1.43)$ & 0.877 & $0.74(0.48-1.14)$ & 0.172 & $0.82(0.53-1.27)$ & 0.368 \\
\hline IR & $0.96(0.75-1.23)$ & 0.730 & $1.04(0.80-1.36)$ & 0.749 & $1.12(0.84-1.50)$ & 0.427 \\
\hline \multicolumn{7}{|l|}{ Education } \\
\hline Complete high school and more & - & - & $3.99(1.06-15.11)$ & 0.041 & - & - \\
\hline
\end{tabular}




\section{DISCUSSION}

Advancement in Medicine has brought gains in patient survival and liver grafting, enabling the care focus of a transplant program to broaden to issues such as quality of life, well-being and religiosity, which are responsible for transforming the experience of the patient in confronting illness. Saving lives proposed by recovery of the liver function can lead to imagining a cure, especially in seriously ill patients in the waiting line for an organ, and concretizes the magnitude of the life-death/finity-infinity dichotomy.

This study first presented the sociodemographic characteristics of patients who are candidates for liver transplantation. The results of this study corroborate two other Brazilian studies in which the majority were male and were in the 49-year-old age group (a little lower than the one found in this study), wherein the majority of the patients $(54.12 \%)$ had low education (elementary education) and monthly family income from zero to four minimum wages (80.0\%), as well as a predominance of the Catholic religion ${ }^{(15-16)}$.

Chronic diseases (such as liver disease) mainly affect the most vulnerable groups, such as populations with low education and income. This is because this population has difficult access to goods and services such as information, education and preventive care ${ }^{(17-18)}$.

Viral hepatitis was the predominant disease in this study (31.3\%), ratifying another performed with candidates from the interior of SP (31.76\%) and with North American candidates $(35.2 \%)^{(19)}$

Although there is an indication for transplantation in the candidates of this study, the majority of patients (70.8\%) presented MELD scores of 10-19, corresponding to a 3-month mortality of only $6.0 \%$, which leads us to believe that the more disabling symptoms of liver diseases are not present in most of the studied population. Moreover, it justifies the fact that the clinical variables did not have an impact on the quality of life in the pre-transplantation phase ${ }^{(20-21)}$.

The impact of the diagnosis and the indication for performing the transplant leads the patient to face a new and unknown reality. Their encounter with the loss of health and proximity to death leads to a paradigm transformation. The patient and his family are permeated by doubts and questions regarding innumerable spheres of their existence. The patient gradually realizes the gravity and precariousness of their life condition and the increasingly evident need for a transplant to survive. In view of the permanence and the inevitability of this situation, the presence of anxiety (inherent in this process) increases, and may even be accompanied by depressive symptoms, requiring adequate interventions by the care team ${ }^{(9)}$.

The inherent severity of the disease leads us to study the psychological impact in these patients: their high rates of anxiety and depressive symptoms are an important finding. The anxiety symptoms may be related to the need for lifestyle changes, physical limitations imposed by the disease, as well as to recent inclusion on the transplant waiting list. This study also found a greater risk of depression in patients with higher education. Patients with higher levels of education appear to have a greater understanding of the disease and its severity, and therefore they may develop a greater risk of depression because they are more in touch with reality ${ }^{(22-23)}$.

It was also possible to observe that patients with up to one monthly MW presented higher mean in the worry domain for quality of life than those with three monthly MW or higher. A study with renal transplant recipients found a positive association between the family income and the emotional domain ${ }^{(24)}$. We can infer that low income, the need for ambulatory follow-up, unexpected hospitalizations, the use of medications not provided by the health system, the request for a balanced diet and the possible withdrawal from work activities are factors that can be identified by the multiprofessional team in order to promote aid and adapt the proposed treatment according to the patient's needs, thus reducing the number of stressors.

The religiosity in the scenario of the illness appears as a support/coping mechanism to face the demands in confronting the new health conditions of these patients. It may also be associated with lower levels of depression, higher rates of hope and well-being ${ }^{(25)}$. This study found low religiosity in organizational and non-organizational items and high intrinsic religiosity (relative to the search for internalization and full experience), as well as positive correlations between the emotional function of the CLDQ and the DUKE score (non-organizational), which indicate that the higher the non-organizational religiosity score, the better the emotional function. This finding shows us the need for the care team to identify and encourage the use of religiosity as a resource for treating these patients. Studies have shown that religiosity is associated with lower patient mortality, including post-liver transplant patients, improved drug adherence and better health behaviors that will be essential for the post-transplant period $^{(8,26-27)}$.

Thus, an evaluation of patients' quality of life, religiosity and anxiety and depressive symptoms should be inserted in the multiprofessional clinical practice. This information enables to gain knowledge on the impact of the disease on daily activities, as well as the factors of coping that benefit the patient in all phases of their treatment. The nurse, a member of the multiprofessional team, actively collaborates in planning and performing the care of these patients, and with their close proximity to the patient and family they also have the possibility to identify their needs with greater ease, and therefore to design strategies together with the team to make the experience of the patient as best as possible in the face of their situation ${ }^{(28-29)}$.

All these characteristics make liver transplantation a complex procedure, which therefore also requires a multiprofessional approach, since it permeates all dimensions of the life of a person and their family, not only solely focused on the transplantation, but rather on the entire illness process. The patient should be summoned to (re)define their life trajectory to adapt to the changes imposed by this context from the diagnosis of the disease and the initial treatment to post-transplant rehabilitation. In this way, religiosity can be considered a coping strategy in facing the new patient's health conditions ${ }^{(30)}$. 
The fact that this study was carried out in a single center may have been a limitation, but it opened the possibility of a future multicenter study in order to compare and also follow this population in the post-transplantation in order to also understand the impact of the transplantation process on the lives of these patients and their families.

\section{CONCLUSION}

The candidates for liver transplantation present medium quality of life, with worse scores in the fatigue and worry dimensions, low levels of organizational and non-organizational religiosity and high intrinsic religiosity index, and a prevalence of anxiety and depressive symptoms. Positive associations were found between: higher education and increased risk of depression, as well as the emotional function (quality of life) of patients and religiosity, which indicates that the greater the non-organizational religiosity, the lower the patient's worry. The findings reinforce the need for the care team to know and use patients' religiosity as a coping strategy.

\section{RESUMO}

Objetivo: Avaliar a qualidade de vida, a religiosidade e os sintomas ansiosos e depressivos em candidatos a transplante de fígado. Método: Estudo epidemiológico e transversal, realizado com candidatos a transplante de fígado acompanhados no ambulatório de um Hospital Universitário, no período de 2014 a 2016. Resultados: Participaram do estudo 50 pacientes, que apresentaram média de idade de 52,5 anos, predominantemente do sexo masculino (58,0\%), com acesso ao ensino fundamental (48,0\%), Model for End Stage Liver Disease entre 10-19 e hepatite viral como etiologia principal. Apresentaram qualidade de vida mediana (escore 4,1), alto índice de religiosidade intrínseca $(5,6)$ e presença de sintomas ansiosos $(52,0 \%)$ e depressivos $(48,0 \%)$. Pôde-se observar associação entre religiosidade e qualidade de vida no domínio preocupação - quanto maior a religiosidade não organizacional, maior a qualidade de vida; sintomas ansiosos e depressivos não associados à qualidade de vida e religiosidade. Porém, pacientes com altos níveis de escolaridade tiveram maior probabilidade de apresentar sintomas depressivos. Conclusão: A análise de qualidade de vida e religiosidade foi significativa, reforçando a necessidade de a equipe assistencial considerá-la como estratégia de enfrentamento da doença.

\section{DESCRITORES}

Transplante de Fígado; Ansiedade; Depressão; Qualidade de Vida; Espiritualidade; Cuidados de Enfermagem.

\section{RESUMEN}

Objetivo: Evaluar la calidad de vida, la religiosidad y los síntomas ansiosos y depresivos en candidatos a trasplante de hígado. Método: Estudio epidemiológico y transversal, realizado con candidatos a trasplante de hígado acompañados en el ambulatorio de un Hospital Universitario, en el período de 2014 a 2016. Resultados: Participaron en el estudio 50 pacientes, quienes presentaron promedio de edad de 52,5 años, predominantemente del sexo masculino (58,0\%), con acceso a la educación básica (48,0\%) Model for End Stage Liver Disease entre 10-19 y hepatitis viral como etiología principal. Presentaron calidad de vida mediana (score 4,1), alto índice de religiosidad intrínseca $(5,6)$ y presencia de síntomas ansiosos $(52,0 \%)$ y depresivos $(48,0 \%)$. Se pudo notar la asociación entre religiosidad y calidad de vida en el dominio preocupación - cuanto mayor la religiosidad no organizativa, tanto mayor la calidad de vida; síntomas ansiosos y depresivos no asociados con la calidad de vida y religiosidad. Sin embargo, pacientes con altos niveles de escolaridad tuvieron mayor probabilidad de presentar síntomas depresivos. Conclusión: El análisis de la calidad de vida y religiosidad fue significativo, subrayando la necesidad de que el equipo asistencial la considere como estrategia de enfrentamiento de la enfermedad.

\section{DESCRIPTORES}

Trasplante de Hígado; Ansiedad; Depresión; Calidad de Vida; Espiritualidad; Atención de Enfermería.

\section{REFERENCES}

1. Meirelles-Júnior RF, Salvalaggio P, Rezende MB, Evangelista AS, Della-Guardia B, Matielo CEL, et al. Liver transplantation: history, outcomes and perspectives. Einstein [Internet]. 2015 [cited 2018 Feb 12];13(1):149-52. Available from: http://www.scielo.br/scielo.php?script=sci_ arttext\&pid=S1679-45082015000100026\&lng=en\&tlng=en

2. Associação Brasileira de Transplante de Orgãos. Registro Brasileiro de Transplantes [Internet]. São Paulo: ABTO; 2017 [citado 2018 fev. 18]. Disponível em: http://www.abto.org.br/abtov03/Upload/file/RBT/2017/rbttrim3-leitura.pdf

3. Malta DC, Bernal RT, de Souza MF, Szwarcwald CL, Lima MG, Barros MB. Social inequalities in the prevalence of self-reported chronic non-communicable diseases in Brazil: national health survey 2013. Int J Equity Health [Internet]. 2016 [cited 2018 Jun 26];15:153. Available from: https://www.ncbi.nlm.nih.gov/pmc/articles/PMC5112650/

4. Nusrat S, Khan MS, Fazili J, Madhoun MF. Cirrhosis and its complications: Evidence based treatment. World J Gastroenterol [Internet]. 2014 [cited 2018 Jun 26];20(18):5442-60. Avaliable from: https://www.ncbi.nlm.nih.gov/pmc/articles/PMC4017060/

5. Medveded ON, Lahdhuis CE. Exploring constructs of well-being, happiness and quality of life. Peer J [Internet]. 2018 [cite 2018 Jun 26];6:e4903. Available from: https://www.ncbi.nlm.nih.gov/pmc/articles/PMC5985772/

6. Alt Y, Grimm A, Schlegel L, Grambihler A, Kittner JM, Wiltink J, et al. The impact of liver cell injury on health-related quality of life in patients with chronic liver disease. PLoS One [Internet]. 2016 [cited 2018 Jun 26];11(3):e0151200. Avaliable from: https://www.ncbi.nlm. nih.gov/pmc/articles/PMC4798400/

7. VanderWeele TJ, Balboni TA, Koh HK. Health and spirituality. JAMA. 2017;318(6):519-20. DOI: 10.1001/jama.2017.8136

8. Fenelon A, Danielsen S. Leaving my religion: understading the relationship between religious disaffiliation, health, and well-being. Soc Sci Res [Internet]. 2016 [cited 2018 Jun 26];57:49-62. Available from: https://www.ncbi.nlm.nih.gov/pmc/articles/PMC4792192/

9. Oliveira PC, Mucci S, Silva e Silva V, Leite RF, Paglione HB, Erbs JL, et al. Assessment of factors related to adherence to treatment in liver transplantation candidates. Transplant Proc. 2016;48(7):2361-5. DOI: http://dx.doi.org/10.1016/j.transproceed.2016.06.032 
10. Lucchetti G, Lucchetti ALG, Peres MF, Leão FC, Moreira-Almeida A, Koenig HG. Validation of the Duke Religion Index: DUREL (Portuguese Version). J Relig Health. 2012;51(2):579-86. DOI: 10.1007/s10943-010-9429-5.

11. Perlin CM, Ferreira VL, Borba HHL, Wiens A, Ivantes CAP, Lenzi L, et al. Quality of life in Brazilian patients with treated or untreated chronic hepatitis C. Rev Inst Med Trop S Paulo [Internet]. 2017 [cited 2018 Jun 26];59:e81. Available from: https://www.ncbi.nlm.nih.gov/ pmc/articles/PMC5738766/

12. Stanhope J. Patient Health Questionnaire-4. Occup Med. 2016;66(9):760-1.

13. Anders K. Resolution of Students t-tests, ANOVA and analysis of variance components from intermediary data. Biochem Med. 2017;27(2):253-8.

14. Wey A, Connett J, Rudser K. Combining parametric, semi-parametric, and non-parametric survival models with stacked survival models. Biostatistics. 2015;16(3):537-49.

15. Mendes KDS, Lopes NLC, Fabbris MA, Castro-e-Silva Júnior O de, Galvão CM. Sociodemographic and clinical characteristics of candidates for liver transplantation. Acta Paul Enferm [Internet]. 2016 [cited 2018 Feb 20];29(2):128-35. Available from: http://www.scielo.br/pdf/ape/ v29n2/en_1982-0194-ape-29-02-0128.pdf

16. Guimaro MS, Lacerda SS, Karam CH, Ferraz-Neto BH, Andreoli PBA. Psychosocial profile of patients on the liver transplant list. Transplant Proc. 2008;40(3):782-4. DOI: 10.1016/j.transproceed.2008.02.040

17. Malta DC, Oliveira TP, Santos MAS, Andrade SCdA, da Silva MA. Progress with the strategic action plan for tackling chronic noncommunicable diseases in Brazil, 2011-2015. Epidemiol Serv Saúde [Internet]. 2016 [cited 2018 Feb 18];25(2):1-2. Available from: http:// www.scielo.br/pdf/ress/v25n2/en_2237-9622-ress-25-02-00373.pdf

18. Isis M, Aguiar F, Augusta V, Braga B. Quality of life in liver transplant recipients and the influence of sociodemographic factors. Rev Esc Enferm USP [Internet]. 2016 [cited 2018 Feb 18];50(3):411-8. Available from: http://www.scielo.br/pdf/reeusp/v50n3/0080-6234reeusp-50-03-0411.pdf

19. Wong RJ, Aguilar M, Cheung R, Perumpail RB, Harrison SA, Younossi ZM, et al. Nonalcoholic steatohepatitis is the second leading etiology of liver disease among adults awaiting liver transplantation in the United States. Gastroenterology. 2015;148(3):547-55. DOI: http://dx.doi. org/10.1053/j.gastro.2014.11.039

20. O'Grady JG, Lake J. Death with low MELD scores and possible implications for organ allocation. Am J Transplant. 2017; 17(9):2238-9. DOI: 10.1111/ajt.14414

21. Aguiar MIF, Braga VAB, Almeida PC, Garcia JHP, Lima CA. Severity of liver disease and quality of life in liver transplantation. Acta Paul Enferm [Internet]. 2016 [cited 2018 Fev 15];29(1)107-14. Avaliable from: http://www.scielo.br/pdf/ape/v29n1/en_1982-0194ape-29-01-0107.pdf

22. Stewart KE, Hart RP, Gibson DP, Fisher RA. Illness apprehension, depression, anxiety, and quality of life in liver transplant candidates: implications for psychosocial interventions. Psychosomatics [Internet]. 2014 [cited 2018 Jun 26];55(6):650-8. Avaliable from: https://www. ncbi.nlm.nih.gov/pmc/articles/PMC3983175/

23. Mucci S. Transplante de fígado: a jornada heróica de recontrução da vida em constante diálogo com a morte. In: Amorin S, Bilotta FA, organizadoras. Jung Saúde: temas contemporâneos. Jundiaí: Paco Editorial; 2014. p. 71-82.

24. Costa JM, Nogueira LT. Association between work, income and quality of life of kidney transplant recipient the municipality of Teresina, PI, Brazil. J Bras Nefrol [Internet]. 2014[cited 2018 Feb 18];36(3):332-8. Available from: http://www.scielo.br/scielo.php?script=sci_ arttext\&pid=S0101-28002014000300332\&lng=en\&nrm=iso\&tlng=en

25. Counted V, Possamai A, Meade T. Relational spirituality and quality of life 2007 to 2017: an integrative research review. Health Qual Life Outcomes. 2018;16(1):75. DOI: 10.1186/s12955-018-0895-x

26. Li S, Stampfer MJ, Williams DR ; VanderWeele TJ. Association of religious Service Attendance with mortality among woman. JAMA Intern Med. 2016;176(6):777-85.

27. Lin CY, Saffari M, Koenig HG, Pakpour AH. Effects of religiosity and religious coping on medication adherence and quality of life among people with epilepsy. Epilepsy Behav. 2018;78:45-51. DOI: 10.1016/j.yebeh.2017.10.008

28. Mendes KDS, Silva Junior OC, Ziviani LC, Rossin FM, Zago MMF, Galvão CM. Educational intervention for liver transplantation candidates. Rev Latino Am Enfermagem [Internet]. 2013 [cited 2018 Feb 28];21(1):419-25. Avaliable from: http://www.scielo.br/scielo.php?script=sci_ arttext\&pid=S0104-11692013000100018\&lng=en\&nrm=iso\&tlng=en

29. Oliveira T, Brasileiro Z, Assis BB, Nogueira DA, Cassia E, Chaves L. Effects of prayer on the vital signs of patients with chronic kidney disease: randomized controlled trial. Rev Esc Enferm da USP [Internet]. 2017 [cited 2018 Feb 28];51:e03236. Available from: http://www. scielo.br/scielo.php?script=sci_arttext\&pid=S0080-62342017000100434\&lng=en\&nrm=iso\&tlng=en

30. Silva DS. Cicatrizes que não se apagam: memórias afetivas e transplante de órgãos. São Paulo, Brasil; 2017. 